\title{
Androgen receptor-dependent and -independent mechanisms mediate Ganoderma lucidum activities in LNCaP prostate cancer cells
}

\author{
BEN-ZION ZAIDMAN ${ }^{1,2}$, SOLOMON P. WASSER ${ }^{2}$, EVIATAR NEVO $^{2}$ and JAMAL MAHAJNA ${ }^{1}$ \\ ${ }^{1}$ Migal, Galilee Technology Center, Cancer Drug Discovery Program, P.O. Box 831, Kiryat Shmona; \\ ${ }^{2}$ Institute of Evolution, University of Haifa, Mount Carmel, Haifa 31905, Israel
}

Received March 8,2007; Accepted April 24, 2007

\begin{abstract}
Ganoderma lucidum (Curt.:Fr.) P. Karst, a medicinal fungus, has been widely used in Asian countries for centuries to prevent or treat a variety of diseases, including cancer. However, the mechanisms responsible for the effects of $G$. lucidum on cancer cells remain to be elucidated. We have previously shown that ethyl acetate extract of G. lucidum inhibits $\mathrm{LNCaP}$ prostate cancer cell viability and proliferation. We also demonstrated that G. lucidum extract decreased androgen receptor transcriptional activity, suppressed levels of secreted prostate-specific antigen, and suppressed androgen receptor protein level. In this study we investigated the mechanisms that underlie the activities of G. lucidum crude extract and its active fraction GLF4 in LNCaP prostate cancer cells. Our data demonstrate that G. lucidum inhibits cell viability by induction of apoptosis through the extrinsic pathway that include activation of caspase- 8 and caspase- 3 and inhibits cell proliferation by the down-regulation of cyclin D1 expression. Furthermore, G. lucidum crude extract and fraction GLF4 interfere with androgen receptor function via competition with the natural ligand dihydrotestosterone and suppression of androgen receptor/androgen response element complex formation. These results indicate that G. lucidum extracts have profound activity against $\mathrm{LNCaP}$ cells that merits further investigation as a potential therapeutic agent for the treatment of prostate cancer.
\end{abstract}

\section{Introduction}

Prostate cancer (PCa) is the most common non-skin malignancy and the third leading cause of cancer deaths worldwide. Prostate

Correspondence to: Dr Jamal Mahajna, Cancer Drug Discovery Program, Migal, P.O.B. 831, Kiryat Shmona 11016, Israel E-mail: jamalm@migal.org.il

Key words: androgen receptor, apoptosis, cell cycle, Ganoderma lucidum, $\mathrm{LNCaP}$, prostate cancer cancer has a complex etiology; presently, age, ethnicity, and family history are the most consistently reported risk factors associated with the disease. Other potential risk factors, such as environmental (1), and dietary (2) factors, have also been suggested. Early-stage prostate cancer that is confined to the prostate gland can be cured by surgical methods (3). In contrast, advanced-stage prostate carcinoma that has metastasized beyond the prostatic capsule is typically treated by androgenablation therapies (4). Androgen ablation therapy exploits the androgen-dependency of prostate cancer cells by either reducing endogenous androgen levels that circulate within the body or by directly blocking androgen receptor (AR) activity with chemical inhibitors (5). However, on occasion, cancer cells escape these treatments and reappear as androgenindependent prostate tumors that proliferate in the absence of androgens (6). This class of prostate tumor is often incurable and ultimately leads to the demise of the patient (7). Accumulating evidence support the concept that prostate cancer progression is accompanied by a shift in reliance on endocrine controls to paracrine and eventually autocrine controls and that this complex process is the result of changes, which occur at molecular levels of cellular control (5). However, the molecular mechanisms involved in the development of androgen-independent prostate cancer are unknown. $A R$ gene mutations enable the receptor to be activated by various ligands (other than DHT) and deregulated growth factors and cytokines (usually with the help of AR coactivators); amplified AR can be activated by very low levels of dihydrotestosterin (DHT). In addition, the loss of PTEN reverses the inhibition of the phosphatidylinositol 3-kinase (PI3-K)-Akt pathway, permitting activated Akt to phosphorylate Bad and IKK and consequently to activate the $\mathrm{NF}-\kappa \mathrm{B}$ pathway, which eventually leads to inhibition of apoptosis and cell survival (8).

Ganoderma lucidum (Curtis: Fr.) P. Karst, is a woody Basidiomycete fungus belonging to the family of Ganodermaceae of Aphyllophorals. It has been widely used in China for the promotion of health and longevity since ancient times. The fungus is a popular health food supplement marketed around the world because of its perceived health benefits, including its anti-cancer properties. In recent years, there has been considerable attention on the anticancer activity 
of G. lucidum (9); however, until now, the mechanism of the anticancer action of G. lucidum was not well understood and, in the past, activation of the immune response of the host by G. lucidum was widely considered as the mechanism responsible for cancer prevention or treatment (10). However, recent studies have shown that in addition to the activation of the immune response of the host, there are other mechanisms by which G. lucidum prevents and/or treats cancer. We, for example, showed recently that ethyl acetate extracts from G. lucidum inhibits LNCaP cell viability and proliferation, cause a G1 phase arrest, suppress levels of secreted prostatespecific antigen (PSA), and decrease androgen and glucocorticoid receptor transcriptional activity in breast cancer MDA-kb2 cells (11). Furthermore, we were able to identify the active fraction of G. lucidum, termed GLF4, which selectively inhibits AR transactivation and competes with DHT for AR binding (Zaidman et al, unpublished data). The present study was undertaken to elucidate the mechanism of action of G. lucidum inhibitory activities in LNCaP prostate cancer cells. Here, we demonstrate that G. lucidum extract and fraction GLF4, inhibit viability and proliferation of LNCaP cells via induction of apoptosis by activation of caspase- 3 via the extrinsic pathway that involves caspase- 8 , induction of a G1 phase arrest through down-regulation of cyclin D1, and interferes with AR function via competition of G. lucidum extracts with the natural ligand DHT and suppression of AR/ARE complex formation.

\section{Materials and methods}

Materials. DHT, hydroxyflutamide (OHF), etoposide, and all other fine chemicals were purchased from Sigma-Aldrich (Rehovot, Israel). Tissue culture media and reagents were purchased from Biological Industries (Beit Haemeq, Israel). Yeast extract and peptone were purchased from BD Diagnostic Systems (Sparks, MD, USA). Ganoderma lucidum (Curt.:Fr.) P. Karst was provided by the Higher Basidiomycetes culture collection at the Institute of Evolution (HAI), University of Haifa, Israel. All antibodies were purchased from Santa Cruz Biotechnology Inc. (Santa Cruz, CA, USA). $\left[{ }^{3} \mathrm{H}\right] \mathrm{DHT}$ (specific activity $100-150 \mathrm{Ci} / \mathrm{mM}$ ) was obtained from Amersham (Piscataway, NJ, USA). Caspase-3, -8, and -9 inhibitors Z-DEVD-fmk, Z-IETD-fmk, and Z-LEHD-fmk, respectively, were purchased from EMD Biosciences, Inc. (San Diego, CA, USA).

Fungus culture and extraction. Ganoderma lucidum growth conditions have been previously described (11). Dry mycelia were ground to fine powder. The powder was extracted with ethyl acetate $(50 \mathrm{ml} / \mathrm{g}$ dry mycelia) for 7 days on a rotary shaker at $160 \mathrm{r} / \mathrm{min}$ at room temperature. Flask content was paper filtered (Whatman no. 1) and solvents were removed under reduced pressure at a temperature of $40^{\circ} \mathrm{C}$. Stock solutions $(50 \mathrm{mg} / \mathrm{ml})$ were prepared in DMSO and stored at $-70^{\circ} \mathrm{C}$. A crude extract was fractionated using a column $(65 \times 4.5 \mathrm{~cm})$ packed with silica gel $60 \AA$, 200-300 mesh. Ethyl acetate extract $(2 \mathrm{~g})$ of $G$. lucidum dry mycelia was eluted with a step gradient of n-Hexane-EtOAc-MeOH. Fraction GLF4 was eluted with n-Hexane-EtOAc-MeOH (1.5:1:0 v/v) and yielded $140 \mathrm{mg}$.
Cell culture. LNCaP prostate cancer (ATCC \# CRL-1740) cells were obtained from ATCC (Rockville, MD, USA). Cells were maintained in RPMI-1640 medium containing $2 \mathrm{mM}$ L-glutamine, 10\% FBS, $100 \mathrm{IU} / \mathrm{ml}$ penicillin, and $100 \mu \mathrm{g} / \mathrm{ml}$ streptomycin. Cells were grown at $37^{\circ} \mathrm{C}$ in a humidified atmosphere with $5 \% \mathrm{CO}_{2}$. Cells were transferred with $0.025 \%$ trypsin and $0.02 \%$ EDTA. Medium and supplements were obtained from Biological Industries (Beit Haemeq, Israel).

Western blot analysis. Cells were plated at $5 \times 10^{5}$ cells in $25 \mathrm{~cm}^{2}$ flasks and after $48 \mathrm{~h}$ they were treated with appropriate substances for an additional $48 \mathrm{~h}$. Cells were collected and washed twice in PBS at $1,000 \mathrm{x}$ f for $6 \mathrm{~min}$ at $4^{\circ} \mathrm{C}$. PBS was removed and cells were lysed in $60 \mu \mathrm{l}$ of lysis buffer $(10 \mathrm{mM}$ Tris pH 7.4, $100 \mathrm{mM} \mathrm{NaCl}, 1 \mathrm{mM}$ EDTA, 1 mM EGTA, $1 \mathrm{mM}$ $\mathrm{NaF}, 20 \mathrm{mM} \mathrm{Na}_{4} \mathrm{P}_{2} \mathrm{O}_{7}, 2 \mathrm{mM} \mathrm{Na} \mathrm{VO}_{4}, 1 \%$ Triton X-100, $10 \%$ glycerol, $1 \mathrm{mM}$ PMSF, $0.1 \%$ SDS, and $0.5 \%$ sodium deoxycholate, supplemented with protease and phosphatase inhibitor cocktails). Cell lysates were centrifuged at 10,000 x g for $10 \mathrm{~min}$ at $4^{\circ} \mathrm{C}$, and supernatant was collected. Protein concentrations were determined using a Bio-Rad assay (Bio-Rad Laboratories, Hercules, CA, USA). Equal amounts of protein $(40 \mu \mathrm{g})$ were fractionated on $8 \%$ SDS-PAGE. The PAGE-fractionated protein extracts were then transferred to nitrocellulose membranes and incubated overnight at $4^{\circ} \mathrm{C}$ with the appropriate primary antibody. Membranes were washed and incubated with HRP-conjugated secondary antibody. Membranes were incubated with Western blot detection reagents (Bio-Rad, Hercules, CA, USA), and visualized on Kodak BioMax MR film (Sigma-Aldrich).

Measuring caspase-3/7 activity. Cells were plated in whitebottom 96-well plates and incubated for $48 \mathrm{~h}$, then $1 \mu \mathrm{l}$ of fungal extracts, in different concentrations, was added. Control wells contained combinations of DMSO, $5 \mathrm{nM}$ DHT, or $5 \mathrm{nM}$ DHT plus increasing concentrations of etoposide (apoptosis inducing agent). For measuring caspase 3/7 activity, Caspase-Glo 3/7 (Promega, Madison, WI, USA) assay was used according to the manufacturer's instructions. Briefly, $100 \mu 1$ of caspase-3/7 reagent was added to each well and plates were incubated for $1 \mathrm{~h}$ at RT. Luminescence was determined using Zenyth 3100 microplate luminometer (Anthos Labtec Instruments Gmbh, Salzburg, Austria) and quantified as RLU. Activity is defined as the fold induction relative to DHT treatment.

Flow cytometric evaluation of Annexin V-FITC/PI-stained cells. LNCaP cells were plated in $25 \mathrm{~cm}^{2}$ flasks and allowed to attach for $48 \mathrm{~h}$. The medium was replaced with $5 \mathrm{ml}$ of phenol-red-free medium supplemented with charcoalstripped serum, and cells were treated with fungal extracts. Following treatment for $48 \mathrm{~h}$, cells were harvested and pelleted by centrifugation at $1,000 \mathrm{x} \mathrm{g}$ for $5 \mathrm{~min}$ at room temperature. Cells were washed twice with cold PBS and resuspended in $1 \mathrm{X}$ binding buffer $(10 \mathrm{mM}$ HEPES $\mathrm{pH} 7.5$, $140 \mathrm{mM} \mathrm{NaCl}, 0.25 \mathrm{mM} \mathrm{CaCl}_{2}$ ) at a concentration of $1 \times 10^{6}$ cells/ml. For staining cells, we used Annexin V-FITC Apoptosis Detection Kit, APOAF (Sigma-Aldrich) according to the manufacturer's instructions. Annexin V-FITC (5 $\mu 1)$ and PI $(10 \mu \mathrm{l})$ were added to $100 \mu \mathrm{l}$ of cells $\left(1 \times 10^{5}\right.$ cells). 
The tube was vortexed gently and incubated in the dark for $10 \mathrm{~min}$ at room temperature. A $1 \mathrm{X}$ binding buffer $(400 \mu \mathrm{l})$ was added to each tube and the samples analyzed by FACScalibur using Cell Quest software (Becton-Dickinson, San Jose, CA).

Preparation of nuclear extracts from LNCaP cells. Cell fractionation was performed using the CelLytic Nuclear extraction kit (Sigma-Aldrich) according to the manufacturer's instructions. All steps were performed at $4^{\circ} \mathrm{C}$, and pre-cooled buffers were used in order to prevent proteolytic degradation of the proteins. The cells were washed twice with 1X PBS and collected in $\sim 600 \mu 1$ of ice-cold $1 \mathrm{X}$ PBS. The cells were harvested by centrifugation at $400 \mathrm{x}$ g for $3 \mathrm{~min}$ at $4^{\circ} \mathrm{C}$, and the pellet was re-suspended in 5 packed-cell volumes (PCV) of the hypotonic lysis buffer (10 mM HEPES pH 7.9, $1.5 \mathrm{mM}$ $\mathrm{MgCl}_{2}, 10 \mathrm{mM} \mathrm{KCl}$ ), containing DTT in a final concentration of $1 \mathrm{mM}$, and a protease inhibitor cocktail in a final concentration of $1 \%$. The cells were incubated for $15 \mathrm{~min}$ on ice allowing them to swell. To swollen cells in hypotonic lysis buffer, 10\% IGEPAL CA-630 solution was added to a final concentration of $0.6 \%$. Cells were homogenized by vortexing vigorously for $10 \mathrm{sec}$. Cells were centrifuged for $30 \mathrm{sec}$ at $10,000 \times \mathrm{g}$. The supernatant (the cytoplasmic fraction) was transferred to fresh tubes and stored at $-70^{\circ} \mathrm{C}$ (after protein concentration determination). The resulting pellet containing 'crude' nuclei was re-suspended in $3 \mathrm{PCV}$ of extraction buffer [10 mM HEPES (pH 7.9), $1.5 \mathrm{mM} \mathrm{MgCl}_{2}, 0.4 \mathrm{M} \mathrm{NaCl}$, 0.2 mM EDTA (pH 8.0), 25\% glycerol] containing DTT in a final concentration of $1 \mathrm{mM}$, and protease inhibitor cocktail in a final concentration of $1 \%$. Tubes were mounted on a vortex mixer and agitated at medium speed for $30 \mathrm{~min}$. Following centrifugation at $20,000 \times \mathrm{g}$ for $5 \mathrm{~min}$, the supernatant (the nuclear fraction) was aliquoted and stored at $-70^{\circ} \mathrm{C}$.

Electrophoretic mobility shift assay (EMSA). Nuclear extracts from LNCaP cells were used for EMSA studies. DNA binding reactions were carried out with $20 \mu \mathrm{g}$ of total protein from nuclear extracts in a total volume of $20 \mu 1$ containing $5 \mathrm{X}$ binding buffer $(1 \mathrm{M}$ Tris $\mathrm{pH} 7.4,2.5 \mathrm{M} \mathrm{KCl}, 0.5 \mathrm{M}$ EDTA pH 8.0, 0.1 M dithiothreitol), $0.5 \mu \mathrm{g}$ poly(dI-dC) Amersham (Piscataway, NJ, USA), and $40 \mathrm{ng}$ of doublestranded ARE oligonucleotide (5'-GTCTGGTACAGGG TGTTCTTTTT-3') (Panomics, Inc., Fremont, CA, USA). Nuclear extracts and ARE were incubated for $30 \mathrm{~min}$ at room temperature and subsequently, protein-DNA complexes were separated under non-denaturing conditions in a $6 \%$ polyacrylamide gel (29:1) containing $2.5 \%$ glycerol and run in $0.5 \mathrm{X}$ TBE $(1 \mathrm{X}=89 \mathrm{mM}$ Tri-borate, $89 \mathrm{mM}$ boric acid, and $2 \mathrm{mM}$ EDTA $\mathrm{pH} 8.0$ ) at $80 \mathrm{~V}$ at room temperature for $90 \mathrm{~min}$. Then, the gel chamber was dismantled, and the gel was incubated for $20 \mathrm{~min}$ in $25 \mathrm{ml} 1 \mathrm{X}$ TBE containing $2.5 \mu \mathrm{l}$ of 10,000X SYBR green (Invitrogen, Carlsbad, CA, USA) nucleic acid gel stain protected from light with gentle agitation. At the end of the incubation period the stain was

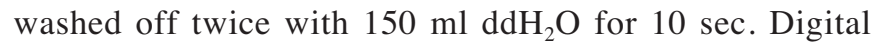
photographs were taken at $300 \mathrm{~nm}$. The band intensity was measured by densitometry.

Competitive binding of $\left[{ }^{3} H\right] D H T$ to the LNCAP AR in the presence of fungal extracts. Competitive binding studies were performed, with modifications, as described by Long et al (12). Twenty-four-well plates were coated with poly-L-lysine $(0.05 \mathrm{mg} / \mathrm{ml})$ for $30 \mathrm{~min}$ and dried. To determine the kinetics of $\left[{ }^{3} \mathrm{H}\right] \mathrm{DHT}$-binding to the LNCaP AR, LNCaP cells $\left(2 \times 10^{5}\right)$ were plated in steroid-free medium and allowed to attach. The following day, the medium was replaced with serum-free, steroid-free RPMI-1640 containing [ $\left.{ }^{3} \mathrm{H}\right] \mathrm{DHT}(0.01-10 \mathrm{nM})$ in the presence or absence of a 200 -fold excess of cold DHT to determine non-specific binding and $1 \mathrm{mM}$ triamcinolone acetonitride to saturate progesterone and glucocorticoid receptors. Following a 2 -h incubation period at $37^{\circ} \mathrm{C}$, cells were washed twice with ice-cold PBS and lysed in PBS containing $0.5 \%$ SDS and $20 \%$ glycerol. Extracts were removed and the cell-associated radioactivity counted in a Tri-carb 2100 TR scintillation counter (Packard Instrument Company, Meriden, CT, USA). The data were analyzed using GraphPad Prism software (GraphPad Software, Inc., San Diego, CA, USA), and $K_{d}$ and $B_{\max }$ determined by Scatchard plot transformation. When the concentration of $\left[{ }^{3} \mathrm{H}\right] \mathrm{DHT}$, required to almost saturate AR in LNCaP cells was established, the ability of the test compounds, in increasing concentrations, to displace $\left[{ }^{3} \mathrm{H}\right] \mathrm{DHT}(3.25 \mathrm{nM})$ from the receptors was determined as described above. Each dilution was performed in triplicate.

\section{Results}

Detecting PARP-1 cleavage following fungal extract treatments. One of the key initiation elements of the apoptotic pathway is the activation of caspases (cysteinyl-aspartic acid proteases) followed by cleavage of the caspase substrates. The 113-kDa poly(ADP-ribose) polymerase 1 (PARP-1) is a nuclear DNA-binding protein normally involved in DNA repair, DNA stability, and other cellular events. Members of the caspase family cleave this protein during early apoptosis. Although PARP is not absolutely required for apoptosis to proceed, the cleavage of PARP may contribute to the commitment to apoptosis. Detection of a $89-\mathrm{kDa}$ or $24-\mathrm{kDa}$ caspase cleavage fragment of PARP-1 was shown to be a hallmark of apoptosis (13). We tested PARP-1 cleavage following treatment with crude organic extract of G. lucidum for $24 \mathrm{~h}$. PARP-1 cleavage could be detected following treatment with $G$. lucidum extracts at concentrations of $80 \mu \mathrm{g} / \mathrm{ml}$ and $120 \mu \mathrm{g} / \mathrm{ml}$ (Fig. 1), arguing for the ability of G. lucidum to induce apoptosis in $\mathrm{LNCaP}$ cells. However, treatment with $1 \mu \mathrm{M}$ of hydroxyflutamide (OHF) failed to induce PARP-1 cleavage.

Measurement of caspase-3 activity in LNCaP cells treated with G. lucidum crude extract and fraction GLF4. To determine if the caspases are involved in fungal extractinduced cell death, LNCaP cells were treated with increasing concentrations of G. lucidum crude extract and GLF4 for $24 \mathrm{~h}$. The topoisomerase II inhibitor etoposide served as a positive control. Caspase- 3 activity was calculated as the fold increase compared to $5 \mathrm{nM}$ DHT-only treated cells. The results indicate that, at the concentration range tested, $G$. lucidum induced apoptosis in LNCaP in a concentrationdependent manner (Fig. 2A). Caspase-3 activity increased as concentration of G. lucidum crude extract and fraction GLF4 


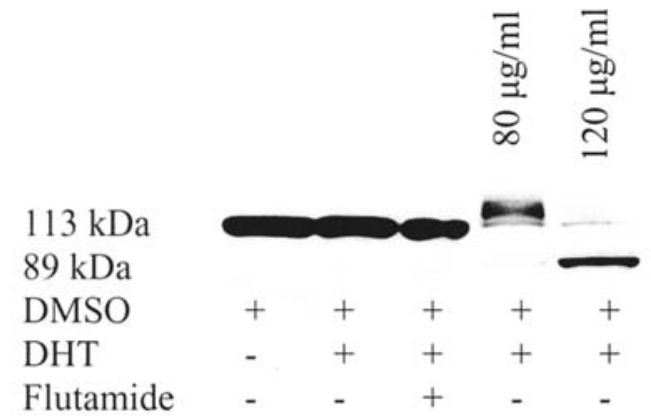

Figure 1. Western blot analysis of PARP-1 cleavage in LNCaP cells. Cells were incubated in phenol-red-free RPMI-1640 containing $10 \%$ charcoal/ dextran-stripped fetal bovine serum for $48 \mathrm{~h}$ followed by treatment with DHT $(5 \mathrm{nM})$ and/or G. lucidum crude extract. DMSO $(0.5 \%)$ and/or hydroxyflutamide (OHF) $(1 \mu \mathrm{M})$ serve as controls. After $24 \mathrm{~h}$ cells were lysed to prepare cellular protein extracts. Aliquots of $40 \mu \mathrm{g}$ total cellular proteins were separated on $8 \%$ SDS gels and transferred to nitrocellulose membranes. PARP cleavage was determined by incubating with mouse antihuman PARP-1 monoclonal antibody (1:2500), followed by a secondary HRP-conjugated goat anti-mouse antibody (1:2500). Immunoreactive signals were detected using a chemiluminescent kit.

A

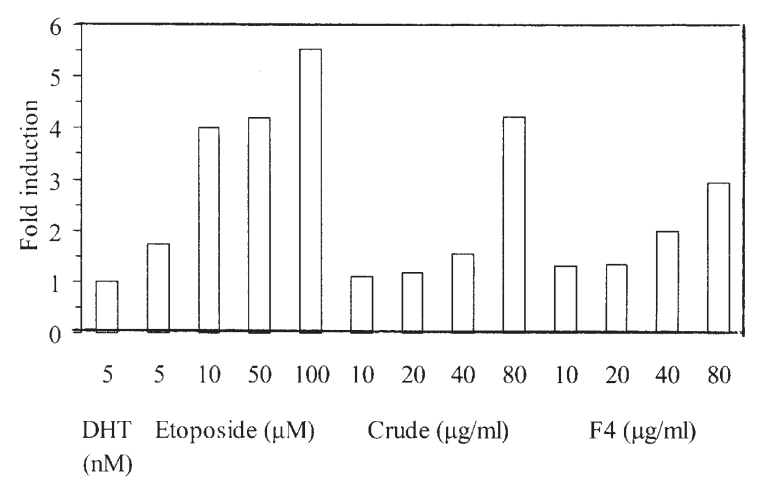

B

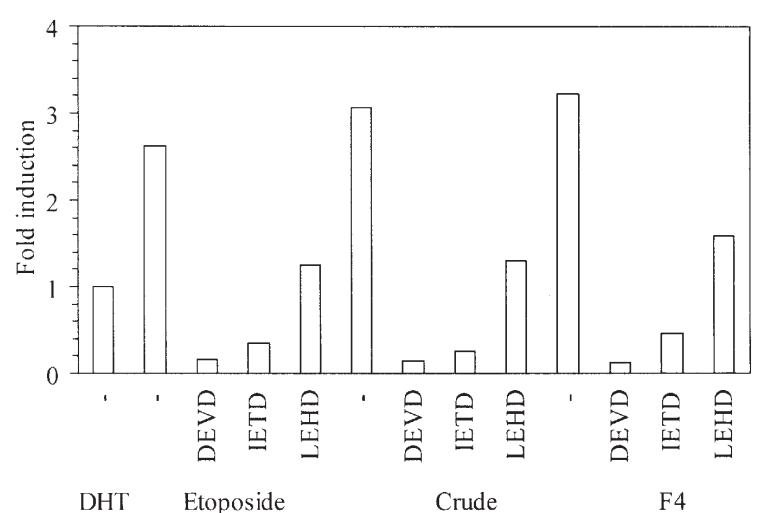

Figure 2. Induction of caspase-3 activity in LNCaP cells by G. lucidum crude extract and fraction GLF4. (A) Response to increasing concentrations of inducer. Cells were seeded in a white wall 96-well plate, and allowed to attach. After $48 \mathrm{~h}$ cells were treated with increasing concentrations of fungal extracts for $48 \mathrm{~h}$. Etoposide served as positive control. (B) Effects of caspase inhibitors on etoposide and G. lucidum-induced apoptosis. LNCaP cells were treated with $5 \mathrm{nM} \mathrm{DHT,} 80 \mu \mathrm{g} / \mathrm{ml} \mathrm{G}$. lucidum crude extract, or $40 \mu \mathrm{g} / \mathrm{ml}$ fraction GLF4 for $48 \mathrm{~h}$. Five $\mu \mathrm{M}$ caspase-3 inhibitor (Z-DEVD-fmk), caspase-8 inhibitor (Z-IETD-fmk) and caspase-9 inhibitor (Z-LEHD-fmk) were added $2 \mathrm{~h}$ prior to treatment with etoposide or $G$. lucidum extracts. In both experiments caspase- 3 reagent was added and plates were incubated for $1 \mathrm{~h}$. Levels of caspase- 3 were monitored using luminometer and quantified as RLU. Fold induction in caspase-3 activity was calculated against DHT-treated cells. increased, reaching a maximum level at a concentration of $80 \mu \mathrm{g} / \mathrm{ml}$. Crude extract at $80 \mu \mathrm{g} / \mathrm{ml}$ was more active by $30 \%$ in inducing caspase-3 activity as compared to fraction GLF4 (Fig. 2A). In addition, topoisomerase II inhibitor etoposide significantly induced caspase- 3 activity in a concentrationdependent manner.

To identify which apical caspase (caspase- 8 or -9) is involved in the initiation of apoptosis induced by G. lucidum extract and fraction GLF4, we used the caspase-3, -8, and -9 inhibitors Z-DEVD-FMK, Z-IETD-FMK, and Z-LEHD-FMK, respectively. With no inhibitor added, the anti-cancer drug etoposide increased caspase-3 activity by 2.6 -fold as compared to DHT-treated cells (Fig. 2B). G. lucidum crude extract and fraction GLF4 induced caspase-3 activity comparable with the effect of etoposide, increasing caspase-3 activity 3 - and 3.2-fold, respectively, over DHT-treated cells (Fig. 2B). When cells were cultured with fungal extracts and the inhibitors Z-DEVD-fmk or Z-IETD-fmk, apoptosis induction was significantly reduced (Fig. 2B). However, when cells were pre-treated with inhibitor Z-LEHD-fmk, G. lucidum crude extract and fraction GLF4 increased caspase-3 activity 1.3- and 1.6-fold, respectively, over DHT-treated cells (Fig. 2B). These results demonstrate that inhibitors of caspase-3 and -8 abrogated caspase- 3 activity induced by G. lucidum crude extract and fraction GLF4. However, inhibitor of caspase-9 was less efficient than the other inhibitors used. Thus, caspase- 3 and -8 are involved in the apoptosisinducing function of G. lucidum crude extract and fraction GLF4.

Annexin V binding and PI influx in LNCaP cells treated with $G$. lucidum crude extract and fraction GLF4. To corroborate our previous data showing apoptosis-inducing ability of $G$. lucidum extract and fraction GLF4, we analyzed the transmigration of PS residues from the inner to outer plasma membrane leaflet - characteristic of programmed cell death. G. lucidum crude extract increased the percentage of annexin V-FITC-positive cells 3.2-, 3.3-, and 4.7-fold in cells treated with 10,40 , and $160 \mu \mathrm{g} / \mathrm{ml} \mathrm{G}$. lucidum crude extract, respectively, compared to control cells (Fig. 3A). $G$. lucidum fraction GLF4 increased the percentage of annexin V-FITC-positive cells 3.0-, 3.4-, and 5.2-fold in cells treated with 10,40 , and $160 \mu \mathrm{g} / \mathrm{ml} \mathrm{G}$. lucidum fraction GLF4, respectively, compared to control cells (Fig. 3B). There was no significant difference between G. lucidum crude extract and fraction GLF4 treatments on annexin VFITC-positive cells at either concentration. PI staining was significantly lower in G. lucidum crude extract and fraction GLF4 treated cells in comparison to annexin V-FITC staining indicating a lack of marked necrosis or increased plasma membrane permeability at the concentration range tested (Fig. 3). There was no significant difference between G. lucidum crude extract and fraction GLF4 treatments on PI-positive cells at either concentration.

G. lucidum crude extract and fraction GLF4 down-regulate cyclin D1. We previously showed (11) that in LNCaP cells treated with G. lucidum extracts, there is an increase in the percentage of the cell population in the G1 phase accompanied with a decrease in the percentage of cell population in the $\mathrm{S}$ phase; an observation that was consistent with a G1 
A

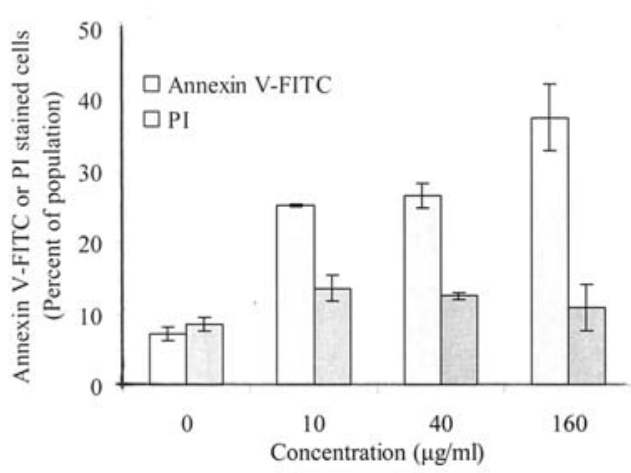

B

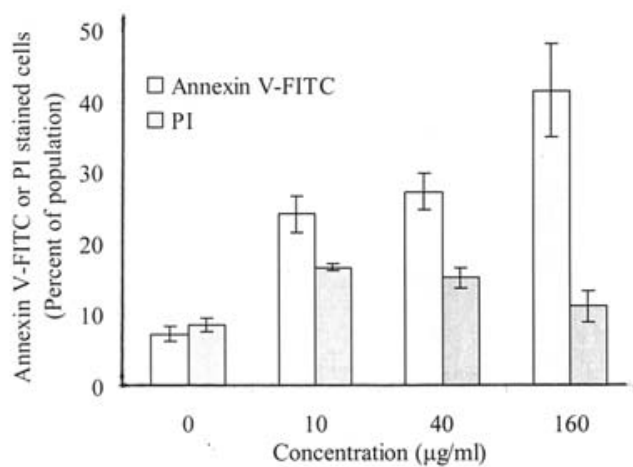

Figure 3. Annexin V-FITC binding and PI influx in LNCaP cells. Cells were incubated for $48 \mathrm{~h}$ with DHT alone or with DHT and increasing concentrations of G. lucidum crude extract (A) and fraction GLF4 (B). Stained cells were analyzed by FACS. Data represent means of 2 replicates and indicate the percentage of cells staining positively for annexin V-FITC or PI. Bars indicate standard deviation.

phase arrest of the cell cycle. To elucidate the mechanisms of G. lucidum crude extract and fraction GLF4-induced cell cycle arrest in LNCaP cells, we evaluated cyclin D1 expression in $\mathrm{LNCaP}$ treated cells by Western blotting. As shown in Fig. 4, both the crude extract and fraction GLF4 markedly decreased the expression of cyclin D1.

\section{Analysis of AR cytoplasmic/nuclear distribution in LNCaP} cells treated with G. lucidum crude extract and fraction GLF4. To examine the effect of G. lucidum extracts on nuclear translocation of the AR, a Western blot analysis was conducted. LNCaP cells were treated with G. lucidum extracts in the presence and absence of $5 \mathrm{nM}$ DHT. Cytoplasmic and nuclear protein fractions were extracted and subjected to Western blot analysis for the AR. DHT treatment cause the accumulation of AR in the nucleus, however, presence of hydroxyflutamide (OHF) alongside DHT prevented nuclear accumulation of AR. In addition, treatment with G. lucidum crude extract prevented nuclear accumulation in a dosedependent manner and consequently cytosolic AR levels were increased. Interestingly, at higher G. lucidum crude extract concentration $(160 \mu \mathrm{g} / \mathrm{ml})$ AR was not detected in either fraction (Fig. 5A). Although activity of G. lucidum crude extract had a much more pronounced effect on nuclear translocation than fraction GLF4, fraction GLF4 also inhibited AR nuclear translocation. At the highest concentration used $(160 \mu \mathrm{g} / \mathrm{ml})$ AR was mainly present in

\begin{tabular}{|c|c|c|c|c|}
\hline \multicolumn{3}{|c|}{ Crude } & \multicolumn{2}{|c|}{$\mathrm{F} 4$} \\
\hline $\begin{array}{l}\bar{E} \\
\text { E. } \\
\text { O } \\
\text { \& }\end{array}$ & $\begin{array}{l}\bar{E} \\
\text { 일 } \\
\text { ○ }\end{array}$ & $\begin{array}{l}\bar{E} \\
\text { 일 } \\
\text { ᄋ }\end{array}$ & $\begin{array}{l}\bar{E} \\
\text { 엠 } \\
\text { 임 }\end{array}$ & $\begin{array}{l}\bar{E} \\
\text { हD } \\
\text { D. } \\
\text { D }\end{array}$ \\
\hline
\end{tabular}

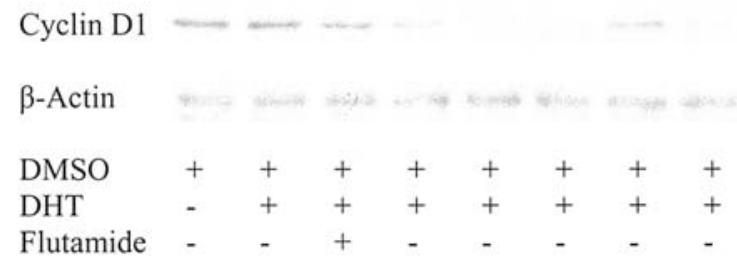

Figure 4. Effect of G. lucidum crude extract and fraction GLF4 on expression of cyclin D1 protein. Cells were treated with increasing concentrations of G. lucidum extracts for $24 \mathrm{~h}$. Total cellular proteins were prepared and Western blotting was performed with an antibody specific for corresponding proteins.

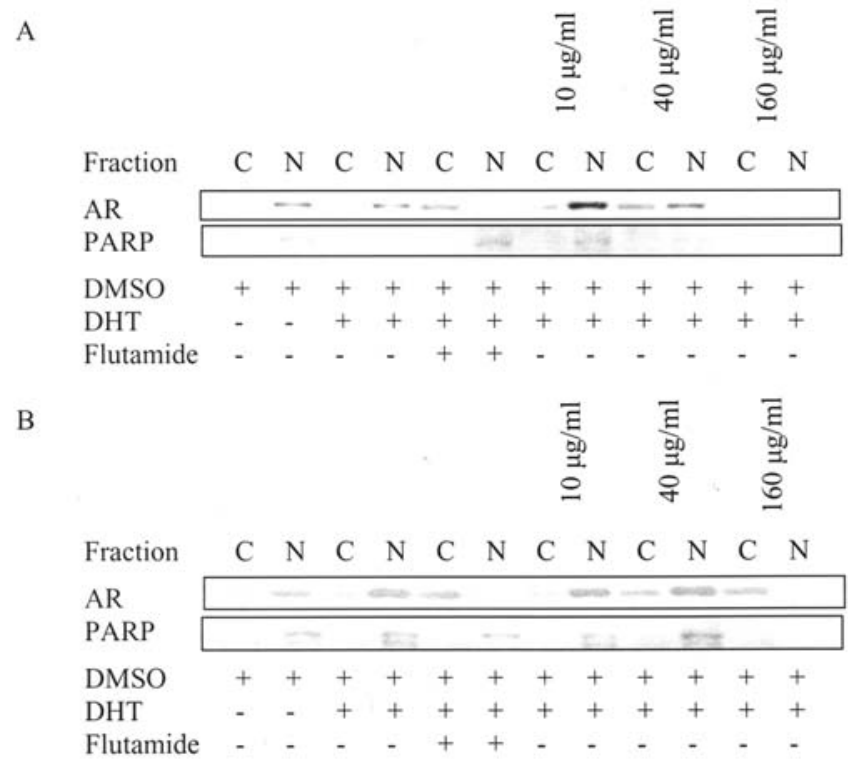

Figure 5. Cellular localization of the AR in LNCaP cells. Effects of G. lucidum crude extract (A) and fraction GLF4 (B) on AR localization. Cells were incubated in phenol-red-free RPMI-1640 containing $10 \%$ charcoal/dextranstripped fetal bovine serum for $48 \mathrm{~h}$ followed by transferring the cells to $1 \%$ charcoal/dextran-stripped fetal bovine serum for an additional $24 \mathrm{~h}$. Cells were treated with DHT $(5 \mathrm{nM})$ and/or fungal extracts. DMSO $(0.5 \%)$ and/or hydroxyflutamide (OHF) $(5 \mu \mathrm{M})$ serve as controls. After 2-h treatment cytosolic and nuclear proteins were extracted. Western blot analysis was performed using antibodies to the AR and PARP. PARP serves as an indicator for nuclear fractions.

the cytoplasmic fraction and absent in the nuclear fraction (Fig. 5B).

DNA binding activity of $G$. lucidum crude extract and fraction GLF4. To explore the effect of G. lucidum extract and fraction GLF4 on binding of AR to ARE, EMSA was employed. The complex formation was observed using the consensus region of ARE and nuclear extracts from LNCaP cells. The treatment of LNCaP cells with DHT (5 nM) enhanced AR/ARE complex formation as compared to non-activated AR (Fig. 6). Hydroxyflutamide $(5 \mu \mathrm{M})$, as a positive control, moderately 


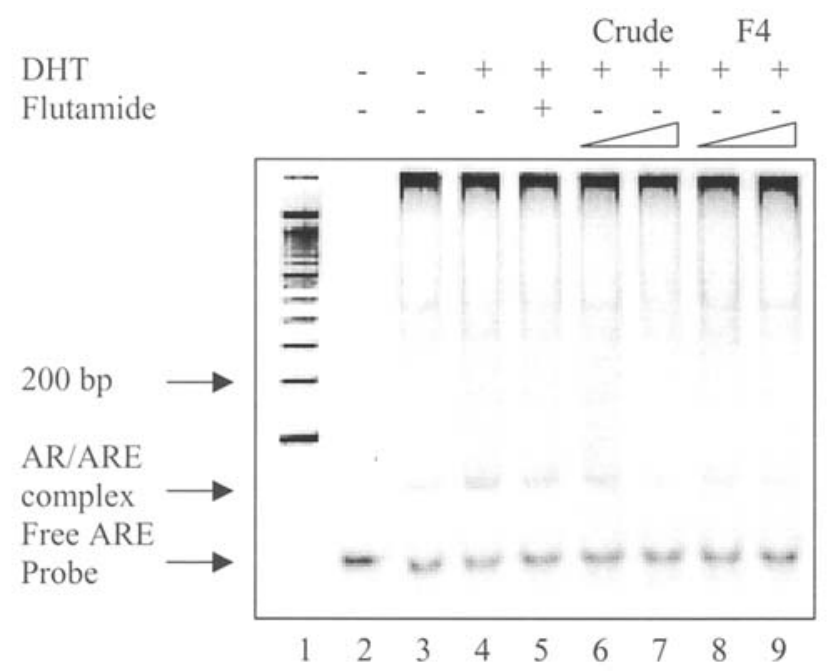

Figure 6. Gel mobility shift analysis of the AR. A 31-bp oligonucleotide consisting of AR responsive element was used for this analysis. Twenty micrograms of nuclear extracts from LNCaP cells were mixed with $0.5 \mu \mathrm{g}$ poly $(\mathrm{dI} \cdot \mathrm{dC})$ and $40 \mathrm{ng}$ DNA fragment and incubated for $20 \mathrm{~min}$ on ice. Samples were analyzed by electrophoresis on native $6 \%$ polyacrylamide gels at $16 \mathrm{~V} / \mathrm{cm}$ for $2 \mathrm{~h}$ at RT. The first lane contains $100-\mathrm{bp}$ DNA ladder. The second lane contains a probe with no nuclear extract. Cells were treated with G. lucidum crude extract at 40 and $120 \mu \mathrm{g} / \mathrm{ml}$ (lanes 6 and 7) and fraction GLF4 at 40 and $120 \mu \mathrm{g} / \mathrm{ml}$ (lanes 8 and 9).

A

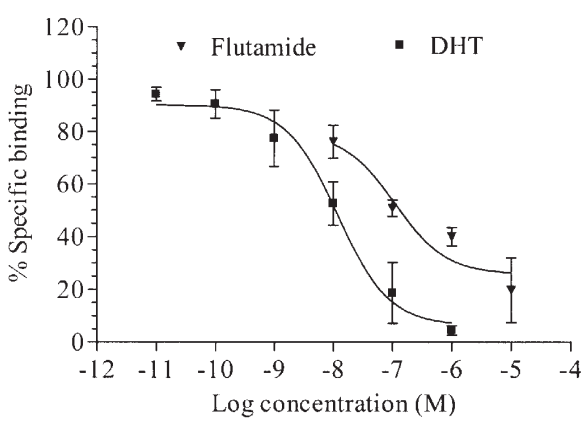

B

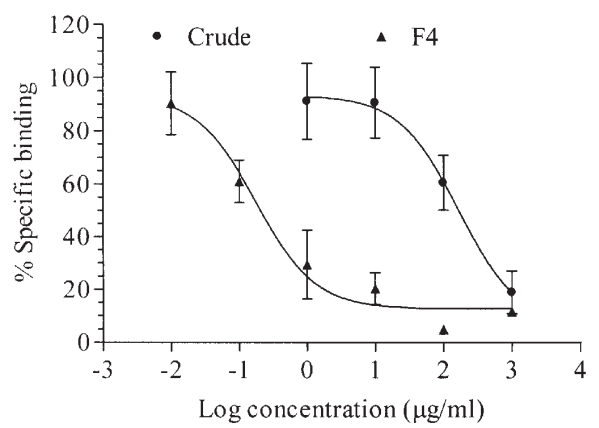

Figure 7. Competitive inhibition of $\left[{ }^{3} \mathrm{H}\right] \mathrm{DHT}$ binding to the AR by G. lucidum crude extract and fraction GLF4. LNCaP cells were incubated with increasing concentrations of each fungal extract in the presence of $3.25 \mathrm{nM}\left[{ }^{3} \mathrm{H}\right] \mathrm{DHT}$. Whole-cell binding assay was performed with (A) DHT, hydroxyflutamide (OHF) as positive control; and G. lucidum crude extract and fraction GLF4 (B). Data are expressed as percentages of the specific binding observed in the non-competing control. The values represent the means \pm SD of two replicates.

inhibited the DHT-stimulated complex formation (Fig. 6). G. lucidum crude extract at concentrations of 40 and $120 \mu \mathrm{g} / \mathrm{ml}$ significantly suppressed the AR/ARE complex formation.
Similarly, G. lucidum fraction GLF4 at concentrations 40 and $120 \mu \mathrm{g} / \mathrm{ml}$ significantly suppressed the AR/ARE complex formation (Fig. 6). These results show that G. lucidum crude extract and fraction GLF4 inhibited binding of DHT-activated AR to the ARE.

G. lucidum crude extract and fraction GLF4 compete with androgen for binding to the AR in LNCaP cells. Since our results strongly implicate the AR as a central factor in mediating the activity of $G$. lucidum crude extract and fraction GLF4 in LNCaP cells, we directly assessed the ability of crude extract and fraction GLF4 to bind to this receptor. As expected, cold DHT and the well-known anti-androgen hydroxyflutamide were able to displace the radioligand with $\mathrm{EC}_{50}$ values of $11.93 \pm 0.13 \mathrm{nM}$, and $0.11 \pm 0.057 \mu \mathrm{M}$, respectively (Fig. 7A). Results from competitive binding assays with the mutant AR of LNCaP cells demonstrate that G. lucidum crude extract and fraction GLF4, in the concentration range tested, compete with labeled DHT for binding to the AR (Fig. 7B). Fraction GLF4 has higher binding affinity than the crude extract as is evidenced by three orders of magnitude lower values of $\mathrm{EC}_{50}$ $(168.7 \mu \mathrm{g} / \mathrm{ml}$ for the crude extract and $0.178 \mu \mathrm{g} / \mathrm{ml}$ for GLF4).

\section{Discussion}

Ganoderma is a Basidiomycete white rot fungus that has been used for medicinal purposes for centuries - particularly in China, Japan, and Korea. Most of the scientific research has been performed on the species, G. lucidum. Paterson (9) nicknamed this fungus 'a therapeutic fungal bio-factory'. Indeed, this fungus produces anti-tumor and hypoglycemic polysaccharides (10), immunomodulatory protein (14), and many bioactive oxygenated triterpenoids. Up to now, over 130 species of triterpenoids and sterols have been isolated from G. lucidum and the genus Ganoderma (15). We have previously reported that $G$. lucidum crude extract inhibits LNCaP cell viability and proliferation, and causes a G1 phase arrest in LNCaP, but not in DU 145 and PC-3 cells. We also demonstrated that $G$. lucidum decreased androgen and glucocorticoid receptor transcriptional activity in breast cancer MDA-kb2 cells, suppressed levels of secreted PSA, and suppressed androgen receptor protein levels in $\mathrm{LNCaP}$ (11). Furthermore, we were able to isolate an active fraction from G. lucidum, termed GLF4, which selectively interfered with AR activity, but not with GR in MDA-kb2 cells and, consequently, inhibited PSA secretion in LNCaP treated cells (Zaidman et al, unpublished data).

In the present study, we examined the mechanisms that underlie the effects of G. lucidum in LNCaP prostate cancer cells. Here, we show that G. lucidum crude extract and fraction GLF4 inhibit cell viability by inducting apoptosis through the extrinsic pathway that include activation of caspase- 8 and caspase-3, and inhibiting cell proliferation by the downregulation of cyclin D1 expression. Furthermore, G. lucidum interfere with the androgen receptor function via competition of compounds present in G. lucidum extracts with the natural ligand DHT and with suppression of AR/ARE complex formation.

We measured three parameters that indicate induction of apoptosis in LNCaP cells: PARP cleavage (Fig. 1), caspase-3 
activity (Fig. 2), and annexin V-FITC staining of externalized PS membranes (Fig. 3). Collectively, these results indicated that $G$. lucidum extract and fraction GLF4 induce apoptosis by triggering the caspase cascade through the extrinsic or death receptor mediated pathway that includes the 'initiator' caspase-8, and the 'effector' caspase-3. The ability of $G$. lucidum extracts to induce apoptosis was demonstrated in several cell lines, e.g., human leukemia, lymphoma and multiple myeloma (16), human breast cancer MCF-7 (17), human prostate cancer PC-3 (18), human hepatoma HuH-7 (19), and human colonic carcinoma HT-29 (20) cell lines. It was shown that a mixture of extracts from $G$. lucidum and the herb Duchesnea chrysantha induce apoptosis in human leukemia HL-60 cells (21). However, as opposed to our findings, in some of these cell lines it was found that $G$. lucidum extracts induce apoptosis through the intrinsic or mitochondrial pathway $(17,19,21)$. Apoptosis is the predominant mechanism by which cancer cells die when subjected to chemotherapy or irradiation. However, cancer cells develop resistance to these therapies that may be due, at least in part, to the development of effective anti-apoptotic mechanisms. For example, in PCa cells there is increased expression of anti-apoptotic proteins of the Bcl-2 family, e.g., Bcl-2, Bcl-xL, and Mcl-1 (22). Another mechanism allowing escape from apoptosis is activation of survival signal transduction pathways. Several survival signaling pathways have been described, some of them are Aktdependent (23), and others are not (24). The best characterized pathway is signaling via activation of PI3K and the protein kinase Akt. Activated Akt protects cells from apoptotic death by phosphorylating substrates such as BAD, procaspase-9, or substrates such as the human telomerase reverse transcriptase subunit, forkhead transcription family members, or IкB kinases that indirectly inhibit apoptosis. In LNCaP PCa cells, Akt is constitutively active as a result of a frame-shift mutation in the PTEN tumor suppressor gene, which encodes a phosphatase that inactivates the lipid products of $\mathrm{PI} 3 \mathrm{~K}$, and, consequently, the $\mathrm{NF}-\kappa \mathrm{B}$ pathway is constitutively activated (25). In a series of experiments, Sliva et al $(26,27)$ and Jiang et al $(18,28)$ showed that G. lucidum extracts inhibit viability, proliferation, and induce apoptosis, which is mediated in part by the inhibition of the $\mathrm{Akt} / \mathrm{NF}-\kappa \mathrm{B}$ signaling in PCa PC-3 and breast cancer MDA-MD-231 cells. The possibility to bypass survival signals makes proapoptotic signaling via death receptors a promising tool for therapeutic intervention in PCa cells, hence, the advantage of G. lucidum extracts.

We have previously shown that G. lucidum fungal extracts blocked LNCaP cell cycle at the transition from G1 to S phase. These results are in accordance with several recent reports showing a G1 phase arrest $(17,18,28-30)$. Interestingly, there are reports indicating a $\mathrm{G} 2$ phase arrest $(18,31,32)$ following treatment with G. lucidum. In this report we demonstrate that the G1 phase arrest is mediated through down-regulation of cyclin D1. These results are in accordance with other studies demonstrating down-regulation of cyclin D1 accompanied with G1 phase arrest $(17,28)$.

Mammalian cell growth and proliferation are mediated via cell cycle progression (33). Progression through the G1 phase of the cell division cycle is a rate-limiting step in mammalian cell proliferation and is governed by numerous mitogenic pathways until the restriction point is passed. CDK4 and CDK6 complexed with cyclin D1 are responsible for cell cycle progression through the G1 phase (34), and the CDK2/cyclin E complex functions in the progression of the cell from late G1 to early S phase (35). These complexes lead to the phosphorylation of retinoblastoma gene product, a tumor suppressor gene that is active in controlling the G1 phase (36). Hyper-phosphorylated pRb leads to its release from the E2F family of transcription factors and induces expression of a number of genes required for S-phase transition (37). We hypothesize, therefore, that down-regulation of cyclin D1 expression caused by G. lucidum will lead to dephosphorylation of $\mathrm{Rb}$ and, consequently, to growth arrest.

The model of AR activation includes several sequential steps. The AR is known to exist as a monomer in the cytoplasm of responsive cells, sequestered in a complex with heat-shock proteins (HSPs). On administration and binding of androgens, the AR changes conformation, and the HSPs are released, followed by a second conformational change. The receptor dimerizes, binds to DNA, and phosphorylation occurs. The DNA-bound receptor interacts with the transcription initiation complex to regulate transcription of genes involved in growth and survival of PCa. We have demonstrated previously that G. lucidum decrease transcriptional activity of the AR (11).

In this report we show that treatment of LNCaP cells with DHT alone induced nuclear translocation of the AR and that co-treatment with G. lucidum crude extract inhibited DHTinduced translocation in a concentration-dependent manner, retaining the $\mathrm{AR}$ in the cytoplasm (Fig. 5A). Co-treatment with fraction GLF4 had an intriguing effect; retaining the AR in the cytoplasm, while levels in the nucleus hardly changed (Fig. 5B). In both treatments it appears that the highest concentration used was toxic to the cells. Moreover, in cells treated with the non-steriodal anti-androgen hydroxyflutamide, most AR was found in the cytoplasmic fraction with very small amounts in the nuclear fraction.

There are conflicting reports regarding the effect of some anti-androgens on AR nuclear import. Early reports demonstrated that the steroidal (e.g., cyproterone acetate) and non-steroidal anti-androgens (e.g., OHF and Bicalutamide) induce nuclear localization at varying degrees $(38,39)$. A more recent study employed an elaborate fractionation of the cell into five distinct subcellular fractions (40). In this study it was shown that in cells treated with OHF and Bicalutamide there was a reversible retention of the AR to the nuclear matrix, whereas in cells treated with cyproterone acetate there is an association of the AR with cytoplasmic membranes and an irreversible retention within the cytoplasm. Both of these anti-androgen groups effectively inhibited transcriptional activity of the AR (41).

Thus, it seems that there are several compounds present in G. lucidum extracts that affect transcriptional activity of the AR. Both G. lucidum crude extract and fraction GLF4 compete effectively with DHT on binding to the AR as was revealed in the competitive binding assay (Fig. 7B). The average binding affinity of fraction GLF4 compounds is much higher than that of crude extract compounds (Fig. 7B). 
Moreover, both the crude extract and fraction GLF4 are able to inhibit DHT-activated AR to ARE as measured by EMSA (Fig. 6). In the highest concentration tested, reduction in DNA binding was almost the same for both fractions. These results imply different mechanisms of action for both the crude extract and fraction GLF4. Our working hypothesis is that G. lucidum crude extract contains substances that compete with DHT on binding to the AR, decrease nuclear localization and decrease DNA binding in a concentrationdependent manner, thus decreasing transcriptional activity. Fraction GLF4 compounds on the other hand, maintain high levels of AR in the nucleus and decrease DNA binding to a constant level regardless of the concentration used. We suggest, therefore, that fraction GLF4, like other antiandrogens, stimulates the assembly of a transcriptionally inactive AR on DNA (42) possibly through inhibition of the interaction with co-activators and/or enhancement of the interaction with co-repressors (43). Thus, some of the substances that regulate AR function, probably by ligand competition, and affect LNCaP cell viability are present in GLF4. However, other compounds that are present in the crude extract and are missing in GLF4 could possibly affect AR indirectly or decrease viability and proliferation of LNCaP cells by different mechanisms.

It is of great interest for us to purify and elucidate the chemical structure of active moieties from $G$. lucidum fraction GLF4. In addition, we are interested in exploiting the natural diversity of the active moieties in quantity and composition found in different species of the same genus and within strains of the selected species.

In conclusion, our data demonstrated that AR-dependent and independent mechanisms underlie the inhibitory activities of G. lucidum extracts in LNCaP prostate cancer cells. Furthermore, our data revealed the possibilities of utilizing G. lucidum in a drug discovery effort aimed at developing bioactive metabolites from G. lucidum that could yield an anti-prostate cancer therapy.

\section{Acknowledgements}

We thank R. Permut (Israel) for the English editing. This research was supported by the Ministry of Science and Technology of Israel, grant no. 3-0561.

\section{References}

1. Hayes RB: Gene-environment interrelations in prostate cancer. Epidemiol Rev 23: 163-167, 2001.

2. Baillargeon J and Rose DP: Obesity, adipokines, and prostate cancer (review). Int J Oncol 28: 737-745, 2006.

3. Naito S: Evaluation and management of prostate-specific antigen recurrence after radical prostatectomy for localized prostate cancer. Jpn J Clin Oncol 35: 365-374, 2005.

4. Miles BJ and Babiarz J: Maximal androgen ablation: a review. Henry Ford Hosp Med J 40: 114-117, 1992.

5. Singh P, Uzgare A, Litvinov I, Denmeade SR and Isaacs JT: Combinatorial androgen receptor targeted therapy for prostate cancer. Endocr Relat Cancer 13: 653-666, 2006.

6. Wright ME, Tsai MJ and Aebersold R: Androgen receptor represses the neuroendocrine transdifferentiation process in prostate cancer cells. Mol Endocrinol 17: 1726-1737, 2003.

7. Hsieh WS and Simons JW: Systemic therapy of prostate cancer. New concepts from prostate cancer tumor biology. Cancer Treat Rev 19: 229-260, 1993.
8. Debes JD and Tindall DJ: Mechanisms of androgen-refractory prostate cancer. N Engl J Med 351: 1488-1490, 2004.

9. Paterson RR: Ganoderma - a therapeutic fungal biofactory. Phytochemistry 67: 1985-2001, 2006.

10. Lin ZB: Cellular and molecular mechanisms of immunomodulation by Ganoderma lucidum. J Pharmacol Sci 99: 144-153, 2005.

11. Zaidman BZ, Wasser SP, Nevo E and Mahajna J: Coprinus comatus and Ganoderma lucidum interfere with androgen receptor function in LNCaP prostate cancer cells. Mol Biol Rep published online: 13 March 2007 DOI: 10.1007/s11033-007-9059-5.

12. Long BJ, Grigoryev DN, Nnane IP, Liu Y, Ling YZ and Brodie AM: Antiandrogenic effects of novel androgen synthesis inhibitors on hormone-dependent prostate cancer. Cancer Res 60: 6630-6640, 2000.

13. Lazebnik YA, Kaufmann SH, Desnoyers S, Poirier GG and Earnshaw WC: Cleavage of poly(ADP-ribose) polymerase by a proteinase with properties like ICE. Nature 371:346-347, 1994.

14. Lin WH, Hung CH, Hsu CI and Lin JY: Dimerization of the $\mathrm{N}$-terminal amphipathic alpha-helix domain of the fungal immunomodulatory protein from Ganoderma tsugae (Fip-gts) defined by a yeast two-hybrid system and site-directed mutagenesis. J Biol Chem 272: 20044-20048, 1997.

15. Gao JJ, Nakamura N, Min BS, Hirakawa A, Zuo F and Hattori M: Quantitative determination of bitter principles in specimens of Ganoderma lucidum using high-performance liquid chromatography and its application to the evaluation of ganoderma products. Chem Pharm Bull 52: 688-695, 2004.

16. Muller CI, Kumagai T, O'Kelly J, Seeram NP, Heber D and Koeffler HP: Ganoderma lucidum causes apoptosis in leukemia, lymphoma and multiple myeloma cells. Leuk Res 30: 841-848, 2006.

17. Hu H, Ahn NS, Yang X, Lee YS and Kang KS: Ganoderma lucidum extract induces cell cycle arrest and apoptosis in MCF-7 human breast cancer cell. Int J Cancer 102: 250-253, 2002.

18. Jiang J, Slivova V, Valachovicova T, Harvey K and Sliva D: Ganoderma lucidum inhibits proliferation and induces apoptosis in human prostate cancer cells PC-3. Int J Oncol 24: 1093-1099, 2004.

19. Li CH, Chen PY, Chang UM, et al: Ganoderic acid X, a lanostanoid triterpene, inhibits topoisomerases and induces apoptosis of cancer cells. Life Sci 77: 252-265, 2005.

20. Hong KJ, Dunn DM, Shen CL and Pence BC: Effects of Ganoderma lucidum on apoptotic and anti-inflammatory function in HT-29 human colonic carcinoma cells. Phytother Res 18: 768-770, 2004.

21. Kim KC, Kim JS, Son JK and Kim IG: Enhanced induction of mitochondrial damage and apoptosis in human leukemia HL-60 cells by the Ganoderma lucidum and Duchesnea chrysantha extracts. Cancer Lett 246: 210-217, 2007.

22. Bruckheimer EM, Spurgers K, Weigel NL, Logothetis C and McDonnell TJ: Regulation of Bcl-2 expression by dihydrotestosterone in hormone sensitive LNCaP-FGC prostate cancer cells. J Urol 169: 1553-1557, 2003.

23. Murillo H, Huang H, Schmidt LJ, Smith DI and Tindall DJ: Role of PI3K signaling in survival and progression of $\mathrm{LNCaP}$ prostate cancer cells to the androgen refractory state. Endocrinology 142: 4795-4805, 2001.

24. Li P, Lee H, Guo S, Unterman TG, Jenster G and Bai W: AKTindependent protection of prostate cancer cells from apoptosis mediated through complex formation between the androgen receptor and FKHR. Mol Cell Biol 23: 104-118, 2003.

25. Deeb D, Jiang H, Gao X, et al: Curcumin sensitizes prostate cancer cells to tumor necrosis factor-related apoptosis-inducing ligand/Apo2L by inhibiting nuclear factor-kappaB through suppression of IkappaBalpha phosphorylation. Mol Cancer Ther 3: 803-812, 2004.

26. Sliva D, Labarrere C, Slivova V, Sedlak M, Lloyd FP Jr and Ho NW: Ganoderma lucidum suppresses motility of highly invasive breast and prostate cancer cells. Biochem Biophys Res Commun 298: 603-612, 2002.

27. Sliva D, Sedlak M, Slivova V, Valachovicova T, Lloyd FP Jr and Ho NW: Biologic activity of spores and dried powder from Ganoderma lucidum for the inhibition of highly invasive human breast and prostate cancer cells. J Altern Complement Med 9: 491-497, 2003.

28. Jiang J, Slivova V, Harvey K, Valachovicova T and Sliva D: Ganoderma lucidum suppresses growth of breast cancer cells through the inhibition of Akt/NF-kappaB signaling. Nutr Cancer 49: 209-216, 2004. 
29. Zhu HS, Yang XL, Wang LB, Zhao DX and Chen L: Effects of extracts from sporoderm-broken spores of Ganoderma lucidum on HeLa cells. Cell Biol Toxicol 16: 201-206, 2000.

30. Yang HL: Ganoderic acid produced from submerged culture of Ganoderma lucidum induces cell cycle arrest and cytotoxicity in human hepatoma cell line BEL7402. Biotechnol Lett 27: 835-838, 2005.

31. Lin SB, Li CH, Lee SS and Kan LS: Triterpene-enriched extracts from Ganoderma lucidum inhibit growth of hepatoma cells via suppressing protein kinase $\mathrm{C}$, activating mitogenactivated protein kinases and G2-phase cell cycle arrest. Life Sci 72: 2381-2390, 2003.

32. Lu QY, Jin YS, Zhang Q, et al: Ganoderma lucidum extracts inhibit growth and induce actin polymerization in bladder cancer cells in vitro. Cancer Lett 216: 9-20, 2004.

33. Ni J, Chen M, Zhang Y, Li R, Huang J and Yeh S: Vitamin E succinate inhibits human prostate cancer cell growth via modulating cell cycle regulatory machinery. Biochem Biophys Res Commun 300: 357-363, 2003

34. Fu M, Wang C, Li Z, Sakamaki T and Pestell RG: Minireview: Cyclin D1: normal and abnormal functions. Endocrinology 145: 5439-5447, 2004.

35. Angus SP, Fribourg AF, Markey MP, et al: Active RB elicits late G1/S inhibition. Exp Cell Res 276: 201-213, 2002.

36. Xu Y, Chen SY, Ross KN and Balk SP: Androgens induce prostate cancer cell proliferation through mammalian target of rapamycin activation and post-transcriptional increases in cyclin D proteins. Cancer Res 66: 7783-7792, 2006.
37. Hofman K, Swinnen JV, Verhoeven G and Heyns W: E2F activity is biphasically regulated by androgens in LNCaP cells. Biochem Biophys Res Commun 283: 97-101, 2001.

38. Kemppainen JA, Lane MV, Sar M and Wilson EM: Androgen receptor phosphorylation, turnover, nuclear transport, and transcriptional activation. Specificity for steroids and antihormones. J Biol Chem 267: 968-974, 1992.

39. Jenster G, Trapman J and Brinkmann AO: Nuclear import of the human androgen receptor. Biochem J 293: 761-768, 1993.

40. Whitaker HC, Hanrahan S, Totty N, et al: Androgen receptor is targeted to distinct subcellular compartments in response to different therapeutic antiandrogens. Clin Cancer Res 10: 7392-7401, 2004.

41. Tyagi RK, Lavrovsky Y, Ahn SC, Song CS, Chatterjee B and Roy AK: Dynamics of intracellular movement and nucleocytoplasmic recycling of the ligand-activated androgen receptor in living cells. Mol Endocrinol 14: 1162-1174, 2000.

42. Masiello D, Cheng S, Bubley GJ, Lu ML and Balk SP: Bicalutamide functions as an androgen receptor antagonist by assembly of a transcriptionally inactive receptor. J Biol Chem 277: 26321-26326, 2002.

43. Song LN, Coghlan M and Gelmann EP: Antiandrogen effects of mifepristone on coactivator and corepressor interactions with the androgen receptor. Mol Endocrinol 18: 70-85, 2004. 